RACAR : Revue d'art canadienne

Canadian Art Review

\title{
Staging Tableaux Vivants in the Theatre of the Dutch Golden Age
}

\section{Stijn Bussels}

Volume 44, numéro 2, 2019

Stay Still: Past, Present, and Practice of the Tableau Vivant Stay Still : histoire, actualité et pratique du tableau vivant

URI : https://id.erudit.org/iderudit/1068319ar

DOI : https://doi.org/10.7202/1068319ar

Aller au sommaire du numéro

\section{Éditeur(s)}

UAAC-AAUC (University Art Association of Canada | Association d'art des universités du Canada)

ISSN

0315-9906 (imprimé)

1918-4778 (numérique)

Découvrir la revue

Citer cet article

Bussels, S. (2019). Staging Tableaux Vivants in the Theatre of the Dutch Golden Age. RACAR : Revue d'art canadienne / Canadian Art Review, 44(2), 79-91.

https://doi.org/10.7202/1068319ar

\section{Résumé de l'article}

Les chercheurs modernes ont trop rapidement pensé que les tableaux vivants sont devenus moins importants durant le Siècle d'or néerlandais. Or, rien ne pourrait être plus faux. Cet article soutient que, durant cette période, la mise en scène de tableaux vivants s'est adaptée de façon particulièrement intéressante à l'influence croissante de la poétique ancienne et que ces tableaux étaient conçus pour occuper différents rôles narratifs et émotionnels dans les pièces dans lesquelles ils apparaissaient. Afin d'établir ceci, je montre d'abord que la tradition des Rhétoriciens en matière de mise en scène de tableaux vivants existait dès le début du XVII ${ }^{\mathrm{e}}$ siècle. Je présente ensuite la performance d'un tableau vivant dans Frères (Gebroeders) de 1641 comme une manière clé pour Joost van den Vondel d'élever le niveau d'émotion à son paroxysme. Enfin, je discute de la pièce la plus populaire du Siècle d'or néerlandais, l'histoire d'une revanche sanglante, Aran et Titus de Jan Vos de la même année, afin de préciser que des façons alternatives d'utiliser le tableau vivant au théâtre étaient également en jeu durant cette période.
Tous droits réservés @ C UAAC-AAUC (University Art Association of Canada | Association d'art des universités du Canada), 2019
Ce document est protégé par la loi sur le droit d'auteur. L'utilisation des services d'Érudit (y compris la reproduction) est assujettie à sa politique d'utilisation que vous pouvez consulter en ligne.

https://apropos.erudit.org/fr/usagers/politique-dutilisation/ 


\title{
Staging Tableaux Vivants in the Theatre of the Dutch Golden Age
}

\author{
Stijn Bussels
}

Les chercheurs modernes ont trop rapidement pensé que les tableaux vivants sont devenus moins importants durant le Siècle d'or néerlandais. Or, rien ne pourrait être plus faux. Cet article soutient que, durant cette période, la mise en scène de tableaux vivants s'est adaptée de façon particulièrement intéressante à l'influence croissante de la poétique ancienne et que ces tableaux étaient conçus pour occuper différents rôles narratifs et émotionnels dans les pièces dans lesquelles ils apparaissaient. Afin d'établir ceci, je montre d'abord que la tradition des Rhétoriciens en matière de mise en scène de tableaux vivants existait dès le début du xvII ${ }^{\mathbf{e}}$ siècle. Je présente ensuite la performance d'un tableau vivant dans Frères (Gebroeders) de 1641 comme une manière clé pour Joost van den Vondel d'élever le niveau d'émotion à son paroxysme. Enfin, je discute de la pièce la plus populaire du Siècle d'or néerlandais, I'histoire d'une revanche sanglante, Aran et Titus de Jan Vos de la même année, afin de préciser que des façons alternatives d'utiliser le tableau vivant au théâtre étaient également en jeu durant cette période.

Stijn Bussels is Full Professor and Chair of the Department of Art History at Leiden University. -s.p.m.bussels@hum.leidenuniv.nl

1. Wim Hummelen, "Types and Methods of the Dutch Rhetoricians Theatre," The Third Globe. Symposium for the Reconstruction of the Globe Playhouse, ed. Walter Hodges et al. (Detroit, 1981): 164-237 and Idem, "Het tableau vivant, de 'toog', in de
In early modern Dutch, tableaux vivants are named toog, vertoog, or vertooning, ${ }^{1}$ terms derived from the verb togen/tonen, which refers to the visual act of displaying, to revealing, and to the act of explaining and elucidating. ${ }^{2}$ These three meanings are essential to understanding the functioning of tableaux vivants in the early modern Low Countries. In essence, the tableau presented a specific message that it captured in a single staged visual display. Because curtains were used to reveal it and, after some time, to conceal it again, the tableau was not constructed gradually, but was put forth suddenly and explicitly. The viewer had a certain amount of time to look at it and to arrive at an understanding of its central message. The resulting ephemerality of the tableau was also an effect of the actors' (sometimes mannequins') frozen poses or very limited movements. ${ }^{3}$ Although the visual dimension of tableaux vivants was of prime importance, it is a misconception that these performances were never accompanied by spoken words or music. In fact, music-often the blast of trumpets-frequently played a crucial role in the revelation of the tableaux, and words were sometimes spoken, albeit within certain parameters (there was, for instance, never to be any contact between people inside and outside the tableau). Figures featuring in the tableau could engage in a short dialogue, and it was not uncommon to let a figure outside the tableau provide some explanation as to what was shown in the tableau, in a kind of explicit embodiment of the third meaning of the verb togen, namely "to elucidate."

This central elucidatory function of the genre is most clearly seen in the exceptional popularity the tableau vivant enjoyed from the fifteenth to the seventeenth centuries as a medium to express political views during joyous entries. When a new ruler was ceremonially presented in the most important cities of the Low Countries, he or she traversed city centres in a rich parade, and numerous tableaux were staged along the route. Thus the organizing municipalities presented their view on concrete political situations to the ruler, his or her retinue, and the many bystanders. While tableaux vivants did play a similar role in other European regions, exceptional care was given to them in the Low Countries, where tableaux began to be staged as early as the mid-fifteenth century, much earlier than in other regions, and remained in use for a very long time, well into the seventeenth. ${ }^{4}$ The tableaux from the Low Countries were also exceptional in quantity and quality. For example, the joyous entry of Charles V and his son Philip into Antwerp in 1549 staged twelve 
toneelspelen van de rederijkers," Tijdschrift voor Nederlandse Taal- en Letterkunde 108 (1992): 193-222.

2. Cf. lemma "togen" in the digital version of the Middelnederlandsch Woordenboek van Verwijs en Verdam: http://gtb.inl.nl/iWDB search?actie $=$ article $\& w d b=M N$ W\&id $=58746 \&$ lemma $=$ togen\&domein $=0 \&$ conc $=$ true (consulted October 1, 2018). Cf. Bart Ramakers, Spelen en figuren. Toneelkunsten processiecultuur in Oudenaarde tussen Middeleeuwen en moderne tijd (Amsterdam: Amsterdam University Press, 1996) and Idem, "Veelzijdig en meerduidig: de tableaux vivants in de Brugse intrede van 1440," in Stad van koopmanschap en vrede: literatuur in Brugge tussen Middeleeuwen en Rederijkerstijd, ed. Johan Oosterman (Leuven: Peeters, 2005): 97-132. For a more general definition of tableaux vivants in this context, see A.M. Karimi, “Tableaux vivants: Their structure, themes, and rhetorical function," Southern Speech Communication Journal 42 (1977): 99-113.

3. Stijn Bussels and Bram Van Oostveldt, "De traditie van de tableaux vivants bij de plechtige intochten in de Zuidelijke Nederlanden (1496-1635)," Tijdschriftvoor Geschiedenis 115 (2002): 151-68.

4. See lemma "toog" in Algemeen letterkundiglexicon, ed. G.J. van Bork et al. https://www.dbnl. org/tekst/dela012alge01_01/ dela012alge01_01_03239.php (consulted October 1, 2018).

5. Stijn Bussels, The Antwerp Entry of Prince Philip in 1549: Rhetoric, Performance and Power (Amsterdam and New York: Rodopi, 2012).

6. By combining iconographical analysis and sociopolitical contextualization, historical studies have looked at the political message that the organizing municipalities wanted to convey through the staging of gods, mythological and legendary heroes, and allegories. (E.g. Hugo Soly, "Plechtige intochten in de steden van de Zuidelijke Nederlanden tijdens de overgang van Middeleeuwen naar Nieuwe Tijd: communicatie, propaganda, spektakel, "Tijdschriftvoor Geschiedenis 97 (1984):341-61.) More recent writings have focused on the medium itself to examine how tableaux were at once strongly embedded in longlasting traditions wherein the same figures were repeatedly staged, and adapted to the specific sociopolitical situation of the moment. (E.g. Margit Thøfner, A Common Art: Urban Ceremonial in Antwerp and Brussels during and after the Dutch Revolt (Zwolle: Waanders, 2007).) Concurrently, scholars have ana- tableaux in which the actors were dressed in the most expensive costumes and which were framed following the latest trend of the grotesque, as the tableaux were surrounded by panels with painted nude acrobatic figures strapped in elaborate scrollwork. ${ }^{5}$

The use of tableaux vivants in late medieval and early modern entries in the Low Countries has received extensive scholarly attention. ${ }^{6}$ This paper will focus instead on the use of tableaux vivants in the theatre, a subject that has been largely neglected. One precedent in English is George Kernodle's 1943 From Art to Theatre, ${ }^{7}$ but as Wim Hummelen has shown, Kernodle's study of only a select number of plays in which tableaux were staged presents a distorted view of their use in the theatre of the Low Countries, and the study is hijacked by its author's main argument, namely that Elizabethan theatre, and more specifically the construction of its stage, was strongly influenced by these tableaux. ${ }^{8}$ It is specifically the theatre in the Dutch Golden Age that I will consider below.

Modern scholars argue for a close link between tableaux vivants and the Rhetoricians (Rederijkers), amateur poets and playwrights who organized in so-called Chambers of Rhetoric (Kamers van Rhetorica) and who dominated cultural life in the fifteenth and sixteenth centuries. ${ }^{9}$ Since the Rhetoricians' influence decreased throughout the seventeenth century, modern scholars all too quickly assumed that tableaux vivants became less important in the theatre as well. Nothing could be further from the truth. The young Dutch Republic underwent an unprecedented cultural effervescence, not only in painting, but also in the theatre, wherein tableaux vivants remained popular. This is undoubtedly surprising, since Dutch theatre was completely transformed in the seventeenth century following the Aristotelian poetic regulation and growing influence of Greek tragedy thanks to humanists such as Daniel Heinsius and Gerardus Vossius, as well as the enormous popularity of revenge plays.

My contention is that the staging of tableaux vivants adapted to these changes, and that tableaux were conceived to occupy different narrative and emotional roles in the plays in which they appeared. To demonstrate this, I will first show that the Rhetoricians' tradition of staging tableaux vivants was extant at the beginning of the seventeenth century. I look at the Cornflower (De Corenbloem), a Chamber of Rhetoric from The Hague, that staged two tableaux vivants in the allegorical play (spel van sinne) they presented at a competition between Chambers organized in The Hague in 1606 . Second, I focus on the performance of Brothers (Gebroeders), a 1641 play by the famous playwright Joost van den Vondel. It marks a turning point in the history of religious theatre, as it is one of the first instances in which a Biblical story is moulded by ancient Greek tragedy. At a crucial moment in the plot, however, Vondel still chose to stage a tableau vivant to raise the level of emotion to its highest pitch. Lastly, I discuss the most popular play from the Dutch Golden Age, the bloody revenge play Aran and Titus by Jan Vos, which premiered a few months after Brothers. Vos used the tableau vivant differently, stripping it of its emotional force, but he did continue to experiment with tableaux vivants in both plays and royal entries later in his carreer. 


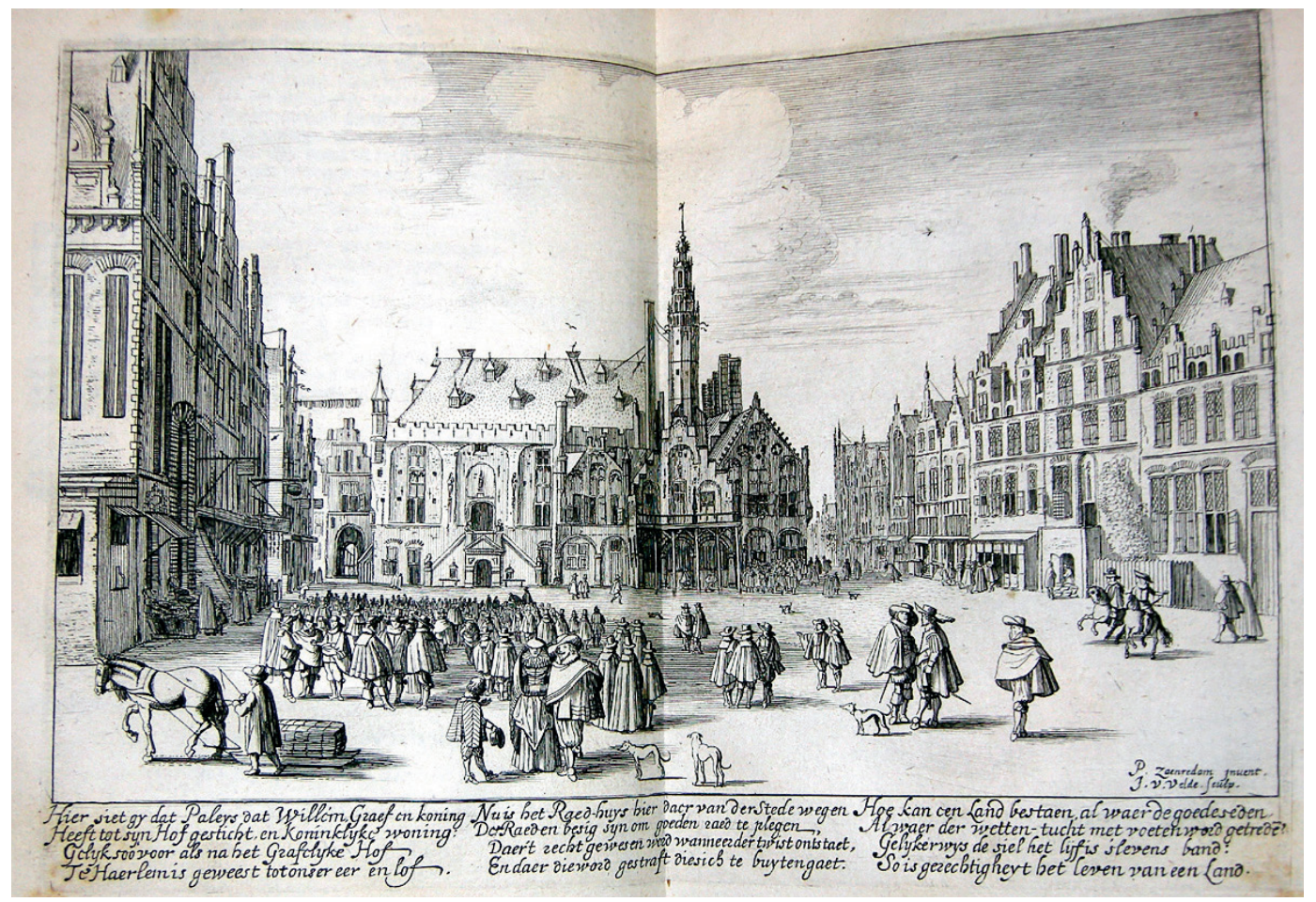

Figure 1. Jan van de Velde after Pieter Jansz. Saenredam, "View of the Market Square in Haarlem," in Samuel Ampzing, Beschryvinge ende lofder stad Haerlem (Haarlem: Adriaen Roman, 1628). Amsterdam, Rijksmuseum. Public domain.

Figure 2. Anonymous, "Theatre Stage of the Haarlem Theatre Competition of 1606 ," in Const-thoonende luweel (Zwolle: Zacharias Heyns, 1607). Photo: Author.

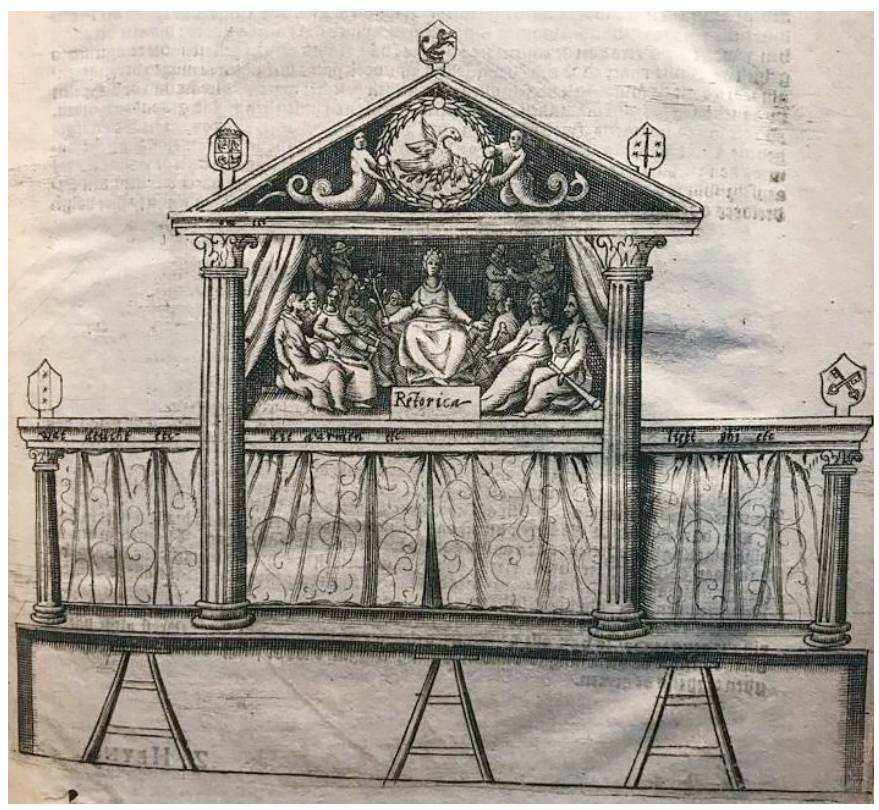




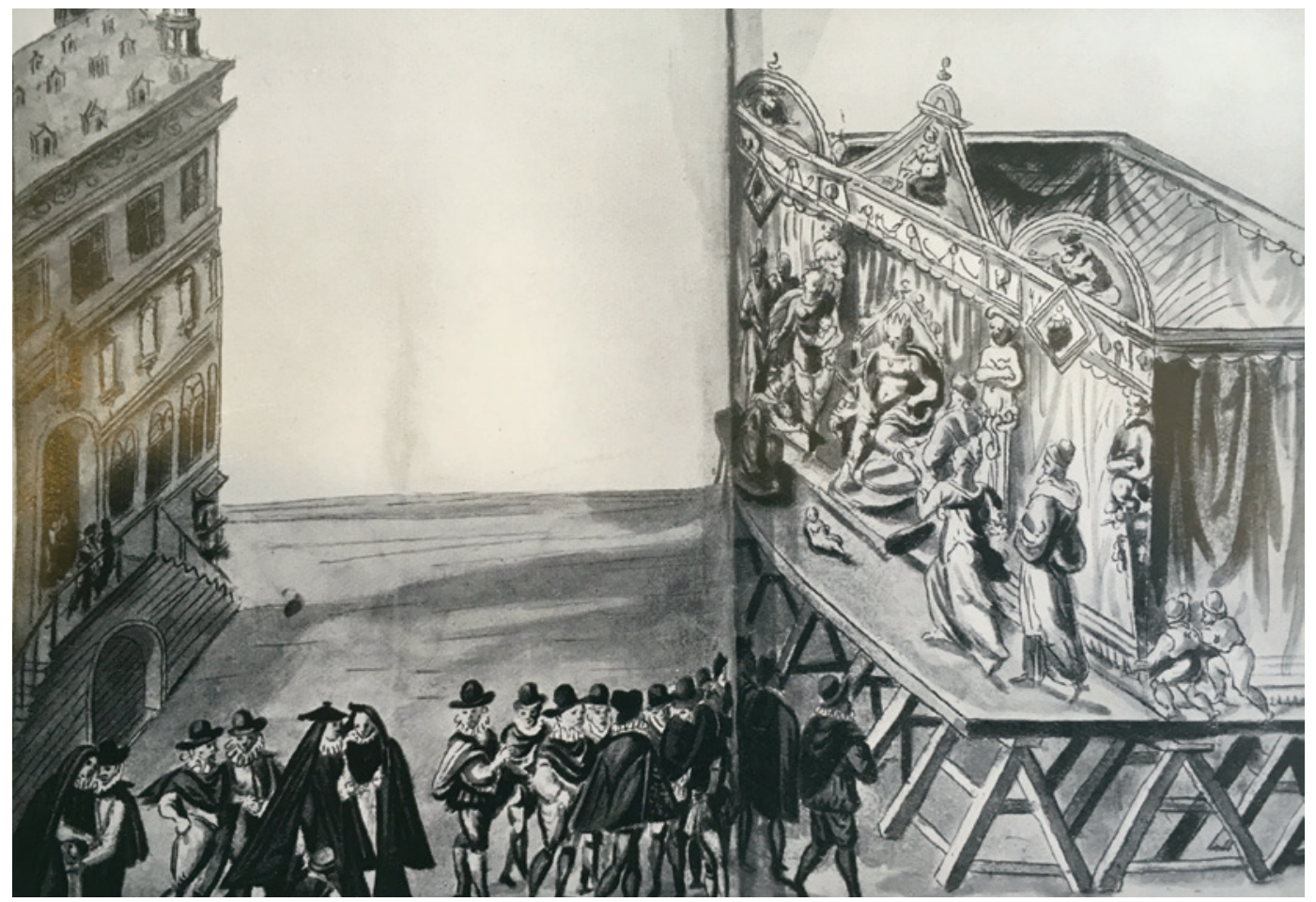

Figure 3. Anonymous,

"Performance of the Judgement of Solomon at Louvain in 1594," in M.A.P.C. Poelhekke et al., Platenatlas bij de Nederlandsche literatuurgeschiedenis (Groningen: Wolters, 1934), fig. 26. Photo: Author.

Figure 4. Dirck Volckertsz. Coornhert after Maarten van Heemskerck, Vision of the Rich Man in Hell, 1551 , engraving, $244 \times 192$ mm. Amsterdam, Rijksmuseum. Public domain.

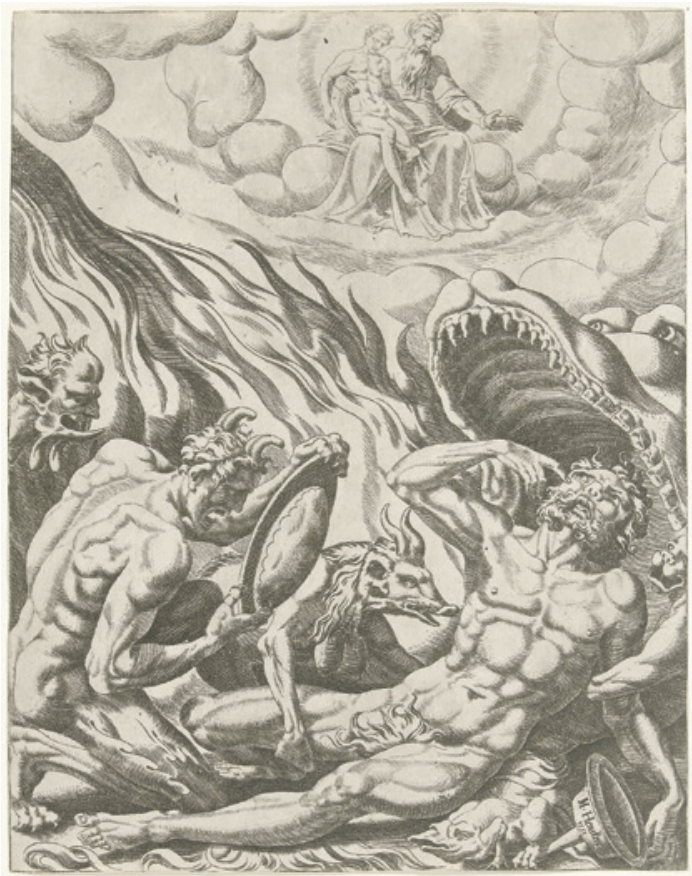


lyzed the ways in which tableaux vivants in joyous entries navigated between the visual arts and the theatre in an attempt to maximize their persuasive potential, e.g., Stijn Bussels, "Tableaux Vivants in Royal Entries, Renaissance and Baroque Painting and the Shifting Concept of Theatricality in the Southern Netherlands," Art History 33 (2011): 38-49.

7. George Kernodle, From Art to Theatre. Form and Convention in the Renaissance (Chicago: University of Chicago Press, 1943). An exception is Hummelen 1981 and Elsa Strietman, "Windows on the Stage. Some Examples of the Use of Imagined Spaces for Religious and Moral Images on the Rhetoricians Stage," European medieval drama 11 (2007): 79-95.

8. Wim Hummelen, "Typen van toneelinrichting bij de rederijkers: De opvattingen van Endepols en Kernodle kritisch onderzocht en geconfronteerd met conclusies op grond van werken van Jacob Duym en Willem van Haecht," Studia Neerlandica 1 (1970): 51-109.

9. See Elsa Strietman and Peter Happé, eds., Urban Theatre in the Low Countries, 1400-1625 (Turnhout: Brepols, 2006).

10. F.C. van Boheemen and Th.C.J. van der Heijden, "De rederijkers en Haarlem," in Haarlems Helicon. Literatuur en toneel te Haarlem vóór 1800, ed. E.K. Grootes (Hilversum: Verloren, 1995), 49-60; Peter Nieuwenhuizen, "Sieraden van vier eeuwen oud: Het Const-thoonend luweel en het Haerlems Juweel; tussen rederijkerij en renaissance," Schoon Schip 13 (2006): 4-11; and Bart Ramakers, "De 'Const' getoond. De beeldtaal van de Haarlemse rederijkerswedstrijd van 1606," in the issue "Hof-, staats- en stadsceremonies," ed. Reindert Falkenburg et al., Nederlands Kunsthistorisch Jaarboek 49 (1998): 128-83.

11. Cf. Hummelen 1992, 195.

12. Previous research has shown that the jury of such theatre competitions looked mainly at the creativity that the Chambers showed to maximize the impact of their performance. Dirk Coigneau, "Rederijkersliteratuur," in Historische letterkunde, ed. Marijke Spies (Groningen: Noordhoff, 1984), 50.

13. The allegorical play of the Cornflower, which was not given a title, is seldom discussed. However, there is a modern edition introduced and annotated by Bart Vandevoorde, Het Const-Thoonende Iuweel. Bijdrage van Den Haag (Ghent: Unedited Master Thesis, 1992).
On October 22, 1606, the Cornflower joined a dozen other Chambers of Rhetoric from the province of Holland in a great theatre competition in Haarlem. ${ }^{10}$ Most attention went to the allegorical plays that the Chambers performed on four consecutive days in the central market square. | fig. 1 | In the volume that assembles all the dramatic texts, Const-thoonende luweel (Art-Revealing Jewel), an etching illustrates how the theatre stage must have appeared. ${ }^{11} \mid$ fig. 2 | A simple platform is supported by benches. Corinthian columns divide the first tier into three parts. On the second tier, the patroness of the Chambers, Lady Rhetorica, sits enthroned, indicating she must have been performed at the ceremonial opening of the competition. Above the stage the seal of the organizing Chamber of the Pelicanists is on display.

The etching clearly shows that the stage had a front stage or proscenium and a space behind a curtain, which we could call a back stage, that was not only used for the actors to rest or to prepare their entry on stage, but for the performance as well. We can relate the Haarlem etching to a drawing from 1594 that illustrates a Rhetorician performance in Louvain, The Judgement of Solomon. | fig. 3 | There are many similarities between the etching and the drawing, but the drawing gives us more insight into the relative depths of the front and back stages: although it was the proscenium that was mostly used, the back stage took up most of the space. The etching and the drawing both reveal that the back stage could be concealed and suddenly revealed thanks to curtains. Moreover, the drawing shows that the backstage was not divided strictly into different sections. Only the columns in the front indicate three compartments, and it is through these that actors could enter the front stage. The Louvain drawing shows they could do this through the lateral sides of the compartments. The interior scenes-actions that took place in a house, a pub, and so on-were performed in these compartments. It is in these spaces that the tableaux vivants were staged, while in the Haarlem competition, they were also presented in the upper compartment.

On the cornice between the two levels of the Haarlem stage, the audience could read the double question that had been presented months in advance to all competing Chambers. The Rhetoricians had to take these questions as starting points to write and stage their allegorical plays: "What reward can those who console the poor with tenderness expect? And what harsh punishment for those who despise tenderness and give no solace?" ("Die d'Armen liefdicht troost, wat loon de sulck verwachte? Als oock wat straffe fel, die troostloos haarveracht?"). Our Rhetoricians of the Cornflower chose to answer these questions in a traditional manner. This might have been the reason why they did not win any important awards. ${ }^{12}$ For us, however, their allegorical play is most interesting precisely for this very reason, since their "old-fashioned" staging confirms that the old-style Rhetorician tableaux vivants that relied on centuries of performances could still be found at the dawn of the Dutch Golden Age. ${ }^{13}$

In the allegorical play, the Cornflower gives centre stage to the figure Almost Anyone (Meest elck), a prototype of the prosperous burgher. Almost Anyone strongly resembles Everyman (Elckerlijc), the famous and influential theatre character who originated in the fifteenth century and who repeatedly, in many plays and under diverse names, came to the conclusion that he 
14. Regarding the first tableau, that is done in the dramatic text itself(vv. 675-676). The second tableau is named in the dramatic text (v. 721), as well as in the stage directions (v. 722)

15. Stage directions in the Art-Revealing Jewel indicate, "The trumpet blown" ("De trompetgheblasen," v. 685).

16. Stage directions in the Art-Revealing Jewel indicate, "Pointing with the left hand" ("Wissendeter slinker handt") v. 702 and "On the left hand" "Terslinkerhand") v. 711.

17. Stage directions in the Art-Revealing Jewel: "Curtain closed" ("Degardijnen toe") v. 718 and "Break" (“Pause") V. 722 was mortal and that after his death, he would have to leave all earthly belongings behind and account for his doings. The same can be said about Almost Anyone in the Cornflower. Throughout the entire play, this figure remains insensitive to the lamentations of his poorer fellow citizens. He disregards the many examples and quotations on charity in the Bible pointed to by figures such as Evangelic Learning (Evangelische leer). But at the very end of the play, Almost Anyone's attitude changes drastically. This occurs immediately after he sees the two tableaux vivants. In the dramatic text of the play published in the Art-Revealing Jewel, the tableaux are explicitly named vertooning. ${ }^{14}$

Significantly, it was not the ceaseless enumeration of Biblical passages that had largely dominated the play, but the sudden appearance of two Biblical moments visually, revealed from behind the curtains, that succeeded in affecting the prototypical prosperous burgher. Almost Anyone is not moved by words, but by images.

The unveiling of the first tableau is accompanied by a blast of the trumpet: ${ }^{15}$ before the eyes of Almost Anyone and the theatregoers, the Last Judgement is suddenly revealed. The fact that the actual revelation of that tableau had to be overwhelming is accentuated by a figure that accompanies Almost Anyone, and who upon suddenly seeing the tableau, exclaims, "What a terrible wondrous work" ("Watten verschrickelicken wonderlick werck") (673). With this strong reaction the figure expresses the exceptional power of the tableau, which provokes terror as well as wonder. At the same time, however, with his choice of the word "work" (werck), he proves that he remains conscious of the fact that he is looking at a representation. After this exclamation of overwhelm, Evangelic Learning gives directions regarding how to look at the tableau: "Stay for a while, since they will show you here in this city [a scene] from Matthew twenty-five" "Vertouft oock een weynich men sal u hier verthoonen/Uyt Matheus vijfen twintich tot deser stede") (674-675). Thus the spectators were urged to carefully look at the tableau and to take their time in order to do so properly. Evangelic Learning's declaration explicitly announces the tableau as a performance.

After these directions aimed at the spectators, an angel recites the verses of the Last Judgement from Matthew 25:31-46. Most probably that angel stood in the upper compartment of the Haarlem stage. The angel pointed at the compartments to the left and right below him. ${ }^{16} \mathrm{He}$ pointed a finger at a miserable figure on his left that he blamed for refusing to help the poor. At the right hand of the angel stood the prototypical exemplary man who during his life had taken pity on the underprivileged and to whom, according to the angel, heaven belonged.

The Rhetoricians of the Cornflower then took a short break in order to reveal a second tableau vivant, ${ }^{17}$ which presented the ultimate moment from the parable of Lazarus. In one of the compartments on the first tier, a figure called Richman (Rijckeman), who resembled Almost Anyone, languished in hell. From there, Richman could see the upper compartment, in which the poor Lazarus was being held in Abraham's bosom, as described in the Bible. In this tableau, the actors spoke: Richman begged for mercy, but Abraham reproached him for never looking after Lazarus, which resulted in his being excluded from heaven.

In these two tableaux, the Rhetoricians of the Cornflower connected strongly with longstanding traditions in the visual culture of the Low 
18. Stijn Bussels, "Hoe overtuigt Coornhert's Comedie vande Rijckeman? Enargeia en het opvoeren van personificaties," Spiegel der Letteren 1 (2008): 1-40.

19. Cf. Stijn Bussels, "Vondel's Brothers and the Power of Imagination," Comparative Drama 49 (2015) 49-68.

20. Vondel's Brothers is discussed in G. Kazemier, "De paradox van Vondels drama Gebroeders," Nieuw Letterkundig Magazijn 4 (1986): 2-4; Jan Konst, Woedende wraakghierigheidt en vruchtelooze weeklachten (Assen: Van Gorcum, 1993), 138-43; Frans-Willem Korsten, Sovereignty as Inviolability: Vondel's Theatrical Explorations in the Dutch Republic (Hilversum: Verloren, 2009), 90-109; Kare Langvik-Johannessen, Zwischen Himmel und Erde: Eine Studie über Joost Van den Vondels biblische Tragödie in Gattungs geschitlicher Perspektive (Oslo: Universitetsforlaget, 1963), 114-32; Karel Porteman, "18 April 1641. In de Amsterdamse Schouwburg gaat Vondels Gebroeders in première. Concept en opvoering van een ambitieus treurspel," in Een theatergeschiedenis der Nederlanden. Tien eeuwen drama en theater in Nederland en Vlaanderen, ed. Rob Erenstein (Amsterdam: Amsterdam University Press, 1996), 218-33; W.A.P. Smit, Van Pascha to Noah: Een verkenning van Vondels drama's naar continuïteiten ontwikkeling in hun grondmotiefen structuur, 3 vols. (Zwolle: Tjeenk Willink, 1956-1962), 1:265-302. For an extensive bibliography on Brothers, see Jan Bloemendal, "Bibliography of Vondel's Dramas (1850-2010)," in Joost van den Vondel (1587-1679): Dutch Playwright in the Golden Age, ed. Jan Bloemendal and Frans-Willem Korsten (Leiden: Brill, 2012), 545-46.

21. Ad Leerintveld, "Een bijzonder exemplaar van Vondels Gebroeders," in Kort tijt-verdrijf: Opstellen over Nederlands toneel (vanafca. 1550) aangeboden aan Mieke B. Smits-Veldt, ed. Wouter Abrahamse and Anneke Fleurkens (Amsterdam: AD\&L Uitgevers, 1996), 157-64; and Mieke B. Smits-Veldt, "De aantekeningen bij Vondels 'Gebroeders' (1644)," Literatuur 8 (1991): 372-73.
Countries. The Last Judgement was often represented with the Archangel Michael in the central position standing between the blessed and the damned, with famous and early examples by Jan van Eyck, Rogier van der Weyden, and Hans Memling. The conclusion of the parable of Lazarus had a rich visual tradition as well. For example, in his Comedy of the Richman (Comedie vande Rijckeman) from 1550, the influential writer and artist Dirck Coornhert had included a scene between Richman and Abraham (but it was not performed as a tableau vivant). ${ }^{18} \mathrm{~A}$ year later, Coornhert took this passage as the central theme for an engraving after a design by Maarten van Heemskerck. | fig. 4 |

Thanks to the two tableaux vivants, Almost Anyone has finally learned his lesson! The tableaux lead the prototypical burgher to the sudden and thorough realization that he has lived entirely the wrong way and he proclaims that from now on he will aid the poor. By providing a crucial moral message-which was presented in a sudden and impactful way before the eyes of the play's central figure-on how to live well and attain heaven, early seventeenth-century tableaux in the Low Countries still corresponded closely to those in the fifteenth and sixteenth centuries. Playwrights sought to influence their audiences through these strong images, and the gaze of their audience was thus explicitly mediated. The inclusion of the tableaux meant that the central figure became a viewer (just like the spectators) within the play, while at the same time giving the example (or in some cases the counter-example) to the theatregoers. The tableaux performers-who already stood out by their sparse use of words and movements-avoided realism and created a belief in the liveliness of what was actually a representation.

\section{Vondel's Brothers}

Joost van den Vondel's Brothers (Gebroeders) premiered in the new Amsterdam playhouse on April 18, $1641 .{ }^{19}$ It enjoyed great success immediately and was performed more than annually for decades. ${ }^{20}$ Inspired by the second book of Samuel, it begins with God's proclamation that justice must be done. Years earlier, King David's predecessor and father-in-law Saul had massacred the Gibeonites. David must avenge them, but faces a moral conflict: he has to choose between his family-in-law and divine justice. After a long period of doubt, David accepts God's will. Seven male descendants of Saul are delivered to the Gibeonites, who hang them. Because David's doubts are at the centre of the play, Vondel calls his drama a tragedy (treurspel). This indicates that he uses the ancient Greek dramatic form, which also focuses on the protagonist's doubt. By doing so, Vondel is one of the first playwrights in early modern Europe to create a Biblical tragedy in a modern language.

Stage directions written in Vondel's hand for the first series of performances of Brothers have been preserved, giving us precious insight into the specific staging. ${ }^{21}$ Vondel was therefore not only the playwright, he was also closely involved in the staging of his tragedy. While this involvement may not have been unique in the seventeenth century, it is rare that staging notes have survived. They indicate that the tragedy marks a shift in Vondel's oeuvre: the executions of Saul's descendants are not staged in a straightforward manner, but as a tableau vivant. This meant the audience was deprived of the blunt cruelties that had been crucial in his previous dramas-for instance 
22. The monologue is published in Joost van de Vondel, De werken van Vondel: Volledige en geillustreerde tekstuitgave, ed. J.F.M. Sterck et al., 10 vols. (Amsterdam: Maatschappij voor goede en goedkope lectuur, 1929), 3:902 (translation by the author).

in Vondel's successful Gysbrecht van Amstel (1639) - as well as in those of many other playwrights of his time, such as Vondel's popular colleague Jan Vos. Not showing the killing straightforwardly meant Vondel could avoid mere abhorrence, and the tableau vivant allowed him to nonetheless create a forceful effect. For this, he relied on the Low Countries tradition-as exemplified in the Cornflower's allegorical play-of using the visual power of tableaux vivants to overwhelm theatregoers by unveiling them suddenly, thus conveying the full understanding of a particular Biblical story.

Although the execution of Saul's descendants is the most essential event in Brothers, surprisingly, it is not staged explicitly. When the execution is nearing, Vondel directs our full attention onto Rizpah. The old woman holds her two soon-to-be-executed sons firmly in her arms in an attempt to prevent their deaths. They know that this is senseless and ask her to kiss them one last time and then to reconcile herself with their fate. This brings her to total despair: hallucinating, she believes that the men in her arms are her two late husbands, Saul and Abner.

Directly after this scene, the action on the stage was stopped to reveal a tableau vivant in which frozen and silent actors (or mannequins) were staged hanging at the gallows. The spectators thus understood that the story had suddenly been brought an important step further, but that the critical event of the story had been skipped, since the execution of Saul's sons and grandsons was already completed. Speed and stillness were paradoxically combined to overwhelm the audience emotionally; Vondel made a big leap and then froze the dramatic action to show a most powerful image. By omitting the performance of cruelties, he could emphasize their terrifying result.

A monologue recited during the tableau vivant heightened the theatregoers' emotional response. The monologue is only found in Vondel's notes. He must have added it during the preparations or rehearsals of the first series of performances. It is not rendered in the printed dramatic text, which predates the premiere of the play. So even those theatregoers who came well prepared to the performance of the tragedy by reading the play in advance would have been surprised to hear the new monologue. Thus its effect must have been overwhelming for all.

The monologue is spoken by one of Rizpah's ladies-in-waiting. She addresses the spectators directly:

Hefop, hefop, met naar geschreeuw,
Aanschouwers treurt met Sauwels weeuw,
Die hier al't koninglijk geslacht
Soo deerlijksiet om hals gebracht,
Maar denkt hoe't moederlijke hart
Ontstelt sij midden in dees smart
Die sij om hare vruchten lijt
Geen mes noch vlim dat scharper snijt,
Als dit dat haar gemoet doorvlimt,
De son daalt neer, den avond klimt,
En valt met drup'len en met douw.
Maer niet een traan ontsijgt dees vrouw,
De moeder lijd de grootste straf.

Nu mach' er niet een traantjen af.
Rise, rise, with bleak screaming. Beholders, mourn with Saul's widow, Who here sees the entire royal family Most dreadfully executed. Imagine how the heart of a mother Is staggered in the midst of the distress That she suffers for her offspring. No knife, no sting cuts sharper Than this that pierces her heart. The sun sets, the evening approaches And falls with drips and dew. But this woman cannot shed a tear. The mother suffers the hardest punishment. Well, can you not give her your tears ${ }^{22}$ 
23. Ben Albach, "De schouwburg van Jacob van Campen," Oud Holland 85 (1970): 85-109, and Wim Hummelen, Inrichting en gebruikvan het toneel in de Amsterdamseschouwburg (Amsterdam: Noord-Hollandsche Uitgeversmaatschappij, 1967). 24. For the influence of Heinsius and Vossius on Vondel, see Bussels, "Vondel's Brothers": 49-68, as well as Stijn Bussels and Bram Van Oostveldt, "Lucifer's Tragedy: How to Find God in the Dutch Golden Age," Dutch Crossing 41, no. 3 (2017): 195-209.

25. A crucial reference on the rise of the rules of bienséance and vraisemblance is still René Bray, La Formation de la doctrine classique en France (Paris: Hachette, 1927). For a recent discussion and bibliography, see the first chapter of Nathalie Kremer, Vraisemblance et représentation au XVIII ${ }^{e}$ siècle (Paris: Honoré Champion, 2011)

26. For the influence on French theoreticians: Edith Kern, The Influence of Heinsius and Vossius upon French Dramatic Theory (Baltimore: Johns Hopkins Press, 1949). For the influence on Vondel: Bussels, "Vondel's Brothers:" 49-68.
The monologue underlines and reinforces the strong emotional effect of the tableau vivant. The lady-in-waiting uses it as a starting point to involve the spectators even more deeply in Rizpah's distress. Vondel does not refrain from staging the execution of Saul's descendants explicitly in order to diminish the emotional impact of the performance. Quite the contrary; he tries to overwhelm the audience. Doing so does not hinder the cathartic effect of the plot, since the straight address that accompanies the tableau urges the onlookers not to become confounded in the way that Rizpah did, but to react appropriately by weeping, since the old woman is no longer able to grieve for her sons and grandsons herself.

Following from the Rhetoricians' tradition of staging tableaux vivants in allegorical plays, Vondel used tableaux first and foremost as a strong visual means of persuasion. The tableau in Brothers had to be revealed suddenly in order to overpower the theatregoers. The engraving depicting the stage of the new Amsterdam playhouse in which the tragedy was premiered shows that, similarly to the Rhetorician stages in Louvain (1594) and Haarlem (1606), curtains were used to reveal compartments at the back where tableaux (and interior scenes) were performed. ${ }^{23} \mid$ fig. $5 \mid$ The monologue accompanying the performance of the tableau of Saul's executed descendants relates to Rhetorician theatre as well since, for centuries, the Chambers of Rhetoric placed narrators in front of tableaux in order to instruct the audience in their interpretation.

An important difference, however, lies in the fact that in Brothers the figure explaining the tableau is sharing time and space with the figures in the tableau. Vondel's tableau differs from the Rhetorician tradition by remaining within the same story, period, and space as the rest of play. Thus Vondel can use the overwhelming power of the tableau vivant yet preserve the Aristotelian unities of action, time, and place as formulated by classical scholars such as Daniel Heinsius and Gerardus Vossius. ${ }^{24} \mathrm{He}$ both relies on an old theatre tradition from the Low Countries and experiments radically by appropriating the ancient Greek theatre model to perform a Biblical story.

But there is even more. The tableau vivant tradition helped Vondel preserve other rules of the theatre that the seventeenth-century reading of Aristotle's and Horace's poetics had put to the fore. First, the rule of propriety, or the demand that the audience should not see any violence or blood on stage. Second, the rule of verisimilitude, which precludes the performance of many atrocities whose staging would not be believable. Both rules would be canonized in France as les règles de bienséance et vraisemblance a few decades after Brothers. ${ }^{25}$ Vondel's close friend, Vossius, who influenced French theoreticians significantly, was already addressing these questions at the time of Brothers, and must have discussed them with Vondel. ${ }^{26}$ The Rhetorician tradition of tableaux vivants offered Vondel the chance to preserve propriety and believability without having to reduce the overwhelming emotional impact on theatregoers.

\section{Vos's Horror}

Vondel's contemporary Jan Vos also experimented with tableaux vivants. In his work, he radically adapted them in order to optimize the impact of the 
Figure 5. Salomon Savery, Stage of the New Amsterdam Playhouse, 1658 , engraving, $513 \times 729 \mathrm{~mm}$. Amsterdam, Rijksmuseum. Public domain.

Figure 6. Closing Scene with the Dead of Aran, in Jan Vos, Aran en Titus, OfWraak en Weerwraak (Amsterdam: Lescaille, 1656), $f^{\circ}$ A2r.
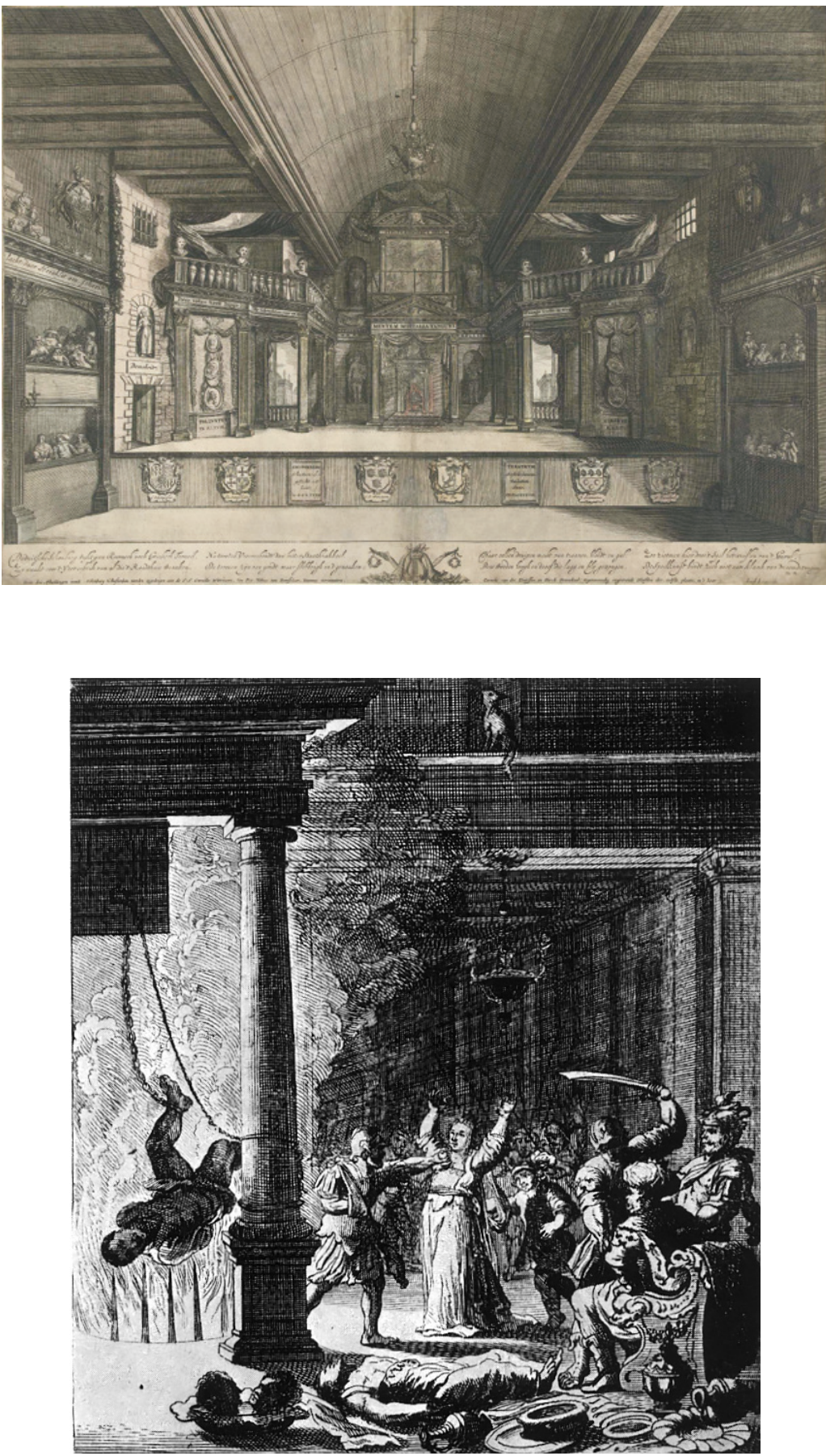
27. The relation with Shakespeare's Titus Andronicus is strongly debated. For an overview of these debates and for an alternative view on the play, see Helmer Helmers, "The Politics of Mobility: Shakespeare's Titus Andronicus, Jan Vos's Aran and Titus and the Poetics of Empire," in Politics and Aesthetics in European Baroque and Classicist Tragedy, ed Jan Bloemendal and Nigel Smith (Leiden: Brill, 2016): 344-72.

28. The most elaborate introduction to the drama is still W.J.C. Buitendijk, "Inleiding," in Jan Vos, Toneelwerken, ed. W.J.C. Buitendijk(Assen: Van Gorcum, 1975): 47-97.

29. The praise is published as Caspar Barlaeus, "Op het hooghdravend Treurspel van Jan de Vos, Glazemaker," in Jan Vos, Alle de gedichten, ed. Jacob Lescaille (Amsterdam: Jacob Lescaille, 1662): A4v.

30. This was not always the case in Dutch revenge plays of this period. For example, a few months after Aran and Titus, Jan Zoet's Thimoklea premiered. It was heavily inspired by Vos's play, but it staged a tableau right at the end. See Rudolf Cordes, Jan Zoet, Amsterdammer, 1609-1674: Leven en werk van een kleurrijkschrijver (Hilversum: Verloren, 2008): 776 .

31. The description of Vos's vertooning is published separately from the dramatic text in Jan Vos, Alle de Gedichten (Amsterdam: Jacob Lescaille, 1662), 578. (https://books.google.be/ books?id=ASZCAAAACAAI\&print$\mathrm{sec}=$ frontcover $\& \mathrm{dq}=\mathrm{jan}+\mathrm{vos}+\mathrm{alle}+$ de+gedichten $+1662 \& h|=n| \& s a=$ X\&ved=oahUKEwjh4q7UsojeAhXSDewKHSIIB4YQ6AEIJzAA\#v=onepage \&q=jan $\% 20$ vos $\% 20$ alle $\%$ 20de $\%$ 2ogedichten $\% 201662 \& \mathrm{f}=$ false, consulted October 1, 2018). joyous entries and the plays in which they were performed. In so doing, he departed even further from Rhetorician performances.

Vos's first feat of arms in the theatre, his revenge play Aran and Titus, premiered a few months after Brothers and was one of the most grisly dramas in the history of Dutch theatre. It shows the gruesome murders committed by Aran, the defeated commander-in-chief of the Goths, who had plotted against the Roman general Titus. Titus in turn reacted with equal cruelty, for instance serving Tamora, queen of the Goths and Aran's most malicious accomplice, her own sons as roast meat. ${ }^{27}$ Aran and Titus was immediately extremely popular and became the most performed play during the Dutch Golden Age. ${ }^{28}$

Laudations linked its enormous success to the explicit staging of murder and bloodshed. Some critics believed Vos had emulated Seneca's Thyestes. The theologian, poet, and historian Caspar Barlaeus, a close colleague of Vossius', received the drama enthusiastically. He praised Vos by stating that he had bested the antique playwrights, for while they had created Orestes, Medea, and the children of Pelops, Atreus and Thyestes, Vos had succeeded in creating characters with utmost malice and atrocity. Barlaeus concluded that the performance of Aran and Titus brought him to total ecstasy, as never before had cruelty been shown so intensely: "I am stupefied. My mind is overwhelmed./ The playhouse is transported, and our theatre is raised to a higher level." ("lk stae gelijk bedwelmt en overstolpt van geest./ De schouburg wort verzet, en schoeyt op hooger leest.") ${ }^{29}$

Barlaeus almost seems to echo the words spoken by the figure accompanying Almost Anyone in the Cornflower allegorical play who had described the overwhelming impact of the Last Judgement tableau vivant-although Barlaeus is of course not a figure in the play, but a spectator. Here, Barlaeus is not referring to a tableau, but to the explicit theatrical performance of slaughter and brutality. Vos does not respect the demand of bienséance and vraisemblance by suddenly revealing a silent scene, as Vondel had a few months earlier. Neither does he freeze the climax of the plot by staging a tableau. Instead, he overwhelms the spectators by staging the fierce struggle between the main characters as a whirlwind of the cruelest actions possible, as illustrated in the 1656 publication of the dramatic text. ${ }^{30} \mid$ fig. 6 |

Vos does not address the demands for propriety and credibility, but he does respect the unities of action, time, and place. In order to do so, he stages a tableau vivant right at the start of the play, before the plot starts to develop, as a way to give the necessary information about what has occurred previously and to introduce the main characters. ${ }^{31}$ In a most impressive display, the tableau shows Titus parading through Rome to publicly celebrate his triumph over the Goths. He is accompanied by the allegories of Fame, Wisdom, Vigilance, and Bravery, as well as allegories that embody the territories he conquered. Tamora, as his most important captive, has to walk in his retinue. At the moment when this tableau is visible, an actor recites a prologue that identifies the figures on stage.

A few years later, Vos began to organize joyous entries and other political celebrations for the Amsterdam burgomasters, thus continuing the centuriesold Rhetorician tradition of staging tableaux vivants in open air to welcome rulers, and he sometimes even restaged these tableaux in the Amsterdam 
32. For example, the tableaux performed on Dam square to celebrate the Peace of Münster in 1648 were also performed in the playhouse a few days later. These tableaux were very influential, including on the decorations for the new Town Hall of which the construction started the same year. Katherine Fremantle, The Baroque Town Hall of Amsterdam (Utrecht: Dekker \& Gumbert, 1959), chapter 2.

33. Jody Enders, "Medieval Snuff Drama," Exemplaria 10 (1998): 171-206. Later further elaborated in Jody Enders, Death by Drama and Other Medieval Urban Legends (Chicago and London: University of Chicago Press, 2002).

34. Mieke B. Smits-Veldt, “De zuster van de Engelse koning Karel II houdt een intocht in Amsterdam, 17 juni 1660," in Nederlandse Literatuur, een geschiedenis, ed. M.A. Schenkeveld-Van der Dussen (Groningen: Martinus Nijhoff, 1993), 265-70.

35. Helmer Helmers, The Royalist Republic: Literature, Politics, and Religion in the Anglo-Dutch PublicSphere, 1639-1660 (Cambridge: Cambridge University Press, 2015).

36. See Jan Vos, Toneelwerken, ed. W.J.C. Buitendijk (Assen: Van Gorcum, 1975), appendix V.

37. Jan Vos, Beschryving der vertoningen, die voor, in, en na't Spel van de Belegering en Ontzet van Leyden, $t^{\prime}$ Amsterdam, in deschouwburg vertoont zijn (Amsterdam: Vinckel, 1663). playhouse. ${ }^{32}$ Whereas Vos had preferred to stage cruelty in full theatrical action instead of as a tableau vivant in his Aran and Titus, he did not refrain from using tableaux to inspire abhorrence during joyous entries. The presentation of blunt violence during such events was exceedingly rare, though not without precedent, as demonstrated by the tableau depicting the murder of Holofernes at the 1549 entry of prince Philip (the later Spanish king Philip II) into Tournai, which was so realistic that it shocked the audience. ${ }^{33}$ Moreover, Vos was innovative by confronting his audience with current political violence.

Most famous is his staging of the execution of Charles I for the welcoming of the king's daughter, Mary Stuart, into Amsterdam in 1660. ${ }^{34}$ The actors in the tableau were not entirely motionless. The allegorical figure Cruel Murder lifted a large axe to cut off Charles's head. This was performed with so much bloodshed that Mary, the guest of honour, fainted. The tableau that followed showed order being restored in England by Mary's husband after this terror. Vos was criticized for the cruelty shown and the tableau's lack of propriety, but even more so for having seemingly become far too involved in political controversies, since the execution of the English king was heavily debated in the Dutch Republic. ${ }^{35}$

In the decades when Vos performed political tableaux vivants outdoors, he also experimented with tableaux in the Amsterdam playhouse of which he was the director from 1647 until his death in 1667 . He was hugely successful in increasing the attractiveness of his colleagues' plays by adding many tableaux. Whereas these series were still called vertoningen, Vos's tableaux increasingly differ from those of the Rhetoricians. ${ }^{36}$ Exemplary are the ones that were staged to improve Reynerius Bontius's Siege and Liberation of the City of Leiden (Belegering ende het ontset der stadt Leyden) of $1660 .{ }^{37}$ Five complex series of tableaux were performed before, during, and after the play in a fixed format that maximally used the depth of the stage.

The order of tableaux in these five series was the same. First, pageant wagons rode to the front stage, often with horrifying allegories, such as Hunger and War. Then, three large and two small compartments opened to reveal tableaux that could be placed in one narrative, e.g., particular cruelties committed by the Spanish army during the Siege of Leiden. After these, the compartments were opened once again to reveal five new tableaux that built further on this narrative. These diverged from the ones that Rhetoricians showed at the end of allegorical plays to give a deeper insight in the plot, as Vos's remained within the time and place of the plot, thus in keeping with Vondel's experiment two decades earlier. The complexity of the chains of tableaux that Vos staged before, during, and after Bontius's play was, however, entirely new. The long series of tableaux were meant to completely overwhelm and confound the theatregoers.

In the climax of his Biblical tragedy Brothers, Joost van den Vondel used a tableau vivant, thus creating an alienating combination of speed and stillness in the performance. Without losing any emotional effect, he could respect the unities of action, time, and place, as well as the rules of believability and propriety, appropriated from ancient poetics. Only a few months after the 
premiere of Brothers, Jan Vos, the successful maker of spectacularly cruel theatre performances and political tableaux, began his career with Aran and Titus, in which he only used one tableau to introduce theatregoers to the story and characters, thus making a clear shift with the tableau vivant tradition that had dominated until the start of the seventeenth century. Later in his career Vos became increasingly interested in tableaux, which he staged outdoors in joyous entries, but even more prominently in theatre performances in the Amsterdam playhouse. In some ways, with these political tableaux he remained within the tradition of the Rhetoricians: for instance, the overwhelming visual surprise that tableaux had caused for centuries was still there when the curtains rose to reveal Vos's tableaux. However, Vos deviated strongly from the Rhetorician tradition by staging astonishingly cruel tableaux and by evacuating the old function of providing explanation and elucidation. Tableaux could now be used to introduce a play or to evoke astonishing stories in most spectacular ways. In Vos's Amsterdam joyous entries and playhouse, the primary function of tableaux vivants was no longer to educate but to shock. q 